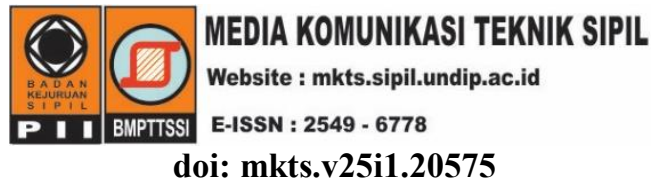

\title{
Pemodelan Perilaku Tegangan dan Regangan Beton pada Suhu Tinggi dengan Software LUSAS
}

\author{
"Reni Suryanita, Wahyu Rahmadhan, Alfian Kamaldi \\ Jurusan Teknik Sipil Fakultas Teknik, Universitas Riau, Pekanbaru \\ *) reni.suryanita@eng.unri.ac.id
}

Received: 6 Oktober 2018 Revised:4 Juli 2019 Accepted: 5 Juli 2019

\begin{abstract}
The concrete structure exposed to high temperatures can affect the strength of the structure. Limitations in the experimental method can be solved by mathematical modeling. This study aims to identify the stress and strain behavior that occurs at high-temperatures. The model is a cylindrical concrete with a diameter of $150 \mathrm{~mm}$ and a height of $300 \mathrm{~mm}$. The concrete strength design is $25 \mathrm{MPa}$. The temperatures of the model are $100{ }^{\circ} \mathrm{C}, 200$ ${ }^{\circ} \mathrm{C}, 300{ }^{\circ} \mathrm{C}, 400{ }^{\circ} \mathrm{C}, 500{ }^{\circ} \mathrm{C}, 600{ }^{\circ} \mathrm{C}$, and $700^{\circ} \mathrm{C}$. The model analysis using LUSAS v. 16 Software to observe the properties of the concrete material due to exposure to high temperatures. The results of the study get the higher the temperature received by concrete, the strength of the concrete decreases. Concrete that burned to a temperature of $300{ }^{\circ} \mathrm{C}$ still had $82 \%$ available power, and at a temperature of $700{ }^{\circ} \mathrm{C}$, the remaining concrete strength was $30 \%$. The strain increases to $423 \%$ from normal conditions at a temperature of $700^{\circ} \mathrm{C}$. Therefore, the results of the study can be used as a reference for structural engineers to know the behavior of the concrete that exposure to high temperatures.
\end{abstract}

Keywords: Mathematical-modelling, high-temperature, LUSAS, stress, strain

\begin{abstract}
Abstrak
Struktur beton yang terpapar suhu tinggi dapat mempengaruhi kekuatan struktur tersebut. Keterbatasan dalam pengujian experimental dapat diatasi dengan pemodelan matematis. Penelitian ini bertujuan untuk mengidentifikasi perilaku tegangan dan regangan beton yang terjadi pada suhu tinggi. Benda uji yang dimodelkan dalam penelitian ini adalah beton berbentuk silinder berdiameter $150 \mathrm{~mm}$ dan tinggi $300 \mathrm{~mm}$. Mutu beton yang dimodelkan adalah $25 \mathrm{MPa}$. Model disimulasikan terpapar suhu secara konstan yang bervariasi dari $100^{\circ} \mathrm{C}, 200^{\circ} \mathrm{C}, 300^{\circ} \mathrm{C}, 400^{\circ} \mathrm{C}, 500^{\circ} \mathrm{C}, 600^{\circ} \mathrm{C}$ dan $700^{\circ} \mathrm{C}$. Analisis model disimulasikan menggunakan Software LUSAS v.16 untuk mengamati sifat material beton akibat terpapar suhu tinggi. Hasil penelitian mendapatkan semakin tinggi suhu yang diterima beton maka kekuatan beton semakin menurun. Beton yang terbakar hingga temperatur $300^{\circ} \mathrm{C}$ masih mempunyai kekuatan yang tersedia $82 \%$ dan pada temperatur $700^{\circ} \mathrm{C}$ kekuatan beton yang tersisa adalah $30 \%$. Pada suhu $700^{\circ} \mathrm{C}$ regangan beton pada tegangan maksimum meningkat menjadi $423 \%$ dari regangan pada kondisi normal. Dengan demikian hasil penelitian ini dapat dijadikan acuan bagi perencana struktur bagaimana perilaku beton ketika terpapar suhu tinggi.
\end{abstract}

Kata kunci: Pemodelan matematis, suhu tinggi, LUSAS, tegangan, regangan

\section{Pendahuluan}

Beton merupakan bahan material yang memiliki sifat non-linear atau elasto-plastik. Namun beton mempunyai kemampuan elastis yang dapat terdeformasi secara permanen akibat pembebanan yang terjadi. Ukuran dari kemampuan elastis beton biasa disebut sebagai modulus elastisitas (modulus young). Modulus ini dapat didefinisikan sebagai perbandingan tegangan yang bekerja dengan regangan yang dihasilkan oleh beton. Secara eksperimental, modulus ini dapat ditentukan dari pengukuran kemiringan dari kurva teganganregangan (stress-strain) yang dihasilkan dalam pengujian kuat tekan beton. Berdasarkan kurva tegangan-regangan beton dapat diprediksi perilaku beton ketika diberikan beban (Sidik, 2010).

Beton merupakan material struktur bangunan yang relatif tahan terhadap api dibandingkan dengan 
material konstruksi lain seperti kayu ataupun baja. Akan tetapi untuk mencapai durabilitas sebagai beton pasca bakar yang memadai tentu diperlukan beberapa persyaratan lain. Salah satu hal penting untuk mencapai durabilitas yang memadai sebagai beton pasca bakar adalah komposisi bahan penyusun beton karena pasta semen dan agregat mengandung komponen yang dapat berdekomposisi setelah pemanasan.

Proses pembakaran merupakan reaksi kimia dari combustible material dengan oksigen, biasa dikenal dengan reaksi pembakaran yang menghasilkan panas. Terdapat dua mekanisme pembakaran yang dapat diterima oleh beton yaitu secara pancaran panas atau radiasi dan secara konveksi. Pembakaran beton secara radiasi akan diterima permukaan beton sehingga temperatur pada permukaan beton meningkat. Pembakaran melalui radiasi ini akan sangat berpengaruh apabila temperatur sumber panas nya relatif tinggi. Kedua secara konveksi yaitu hawa panas yang berhembus ataupun bersinggungan langsung dengan permukaan beton yang mengakibatkan temperatur pada permukaan beton meningkat. Sifat termal beton ditemukan sangat bervariasi dengan jenis dan jumlah agregat dalam beton.

Konduktivitas termal (thermal conductivity) merupakan fenomena transport dimana perbedaan temperatur mengakibatkan adanya transfer energi thermal dari satu benda panas ke daerah yang sama pada suhu yang lebih rendah. Konduktivitas termal juga menyatakan kemampuan dari suatu bahan untuk mengantarkan kalor. Thermal conductivity beton biasanya bervariasi sesuai aliran panasnya. Pada beton normal, nilai thermal conductivity cenderung menurun sedangkan suhu mengalami peningkatan. Nilai dan perubahan pada thermal conductivity dengan suhu, bagaimanapun bergantung pada kristanilitas (tingkat kristalisasi pada suatu material) agregat. Semakin tinggi tingkat kristanilitas, maka semakin tinggi thermal conductivity bersamaan dengan penurunan suhu. Pada beton ringan, thermal conductivity cenderung meningkat diikuti dengan kenaikan suhu, namun nilai tersebut hampir mendekati konstan.

Sifat material yang mempengaruhi kenaikan suhu dan distribusi baja struktur adalah thermal conductivity dan specific heat. Suhu meningkat pada baja sebagai hasil dari aliran panas adalah fungsi dari thermal conductivity material. Nilai dari properties ini bervariasi terhadap komposisi kimia pada suhu ruangan. Namun, pada suhu tinggi dapat dianggap identik pada kebanyakan struktur baja. Selain itu, sifat yang sangat mempengaruhi perilaku beton dalam jangka panjang yaitu konduktifitas panas (thermal conductivity) dan kalor jenis (specific heat). Konduktifitas panas (thermal conductivity) merupakan rasio dari perubahan energi panas. Konduktifitas dari beton terggantung dari komposisi beton dan kadar air yang ada pada beton tersebut. Secara umum konduktifitas beton berkisar antara $1,4-3,6 \mathrm{~J} / \mathrm{m}^{2} \mathrm{~s}^{\circ} \mathrm{C}$. Menurut Lie (1992) konduktifitas dari beton bervariasi tergantung dari aliran panas yang diterima beton. Pada beton normal konduktifitas cenderung menurun ketika suhu meningkat, sedangkan pada beton ringan konduktifitas meningkat seiring dengan peningkatan suhu. Kalor jenis (specific heat) dinyatakan sebagai kapasitas panas beton. Kapasitas panas beton ini akan bertambah sejalan dengan bertambahnya kandungan air pada beton.

Perilaku beton yang terpapar suhu tinggi juga dapat diketahui dari tegangan-regangan yang dihasilkan dari pengujian kuat tekan beton. Peneliti terdahulu sudah berhasil mengkaji perilaku beton bertulang pasca kebakaran seperti yang dilakukan oleh, Nyoman (2015), Rizal (2017), Cornelis at al (2014), dan Herlambang \& Sudiarta (2015). Beton yang terpapar suhu tinggi hingga 200 derajat celsius dapat memberikan peningkatan pada kekuatan tekan beton hingga $20 \%$ dibandingkan pada suhu normal tanpa kenaikan derjat celsius $\left(0^{\circ} \mathrm{C}\right)$. Hal tersebut disebabkan oleh penguapan air (dehidrasi) dan penetrasi ke dalam rongga-rongga beton terjadi lebih dalam, sehingga memperbaiki sifat lekatan antar partikel Calcium Silicate Hydrate (C-S-H). Namun jika dipanaskan terus hingga lebih dari $500^{\circ} \mathrm{C}$, degradasi kekuatan yang signifikan terjadi hingga 50\% seperti terlihat pada Gambar 1.

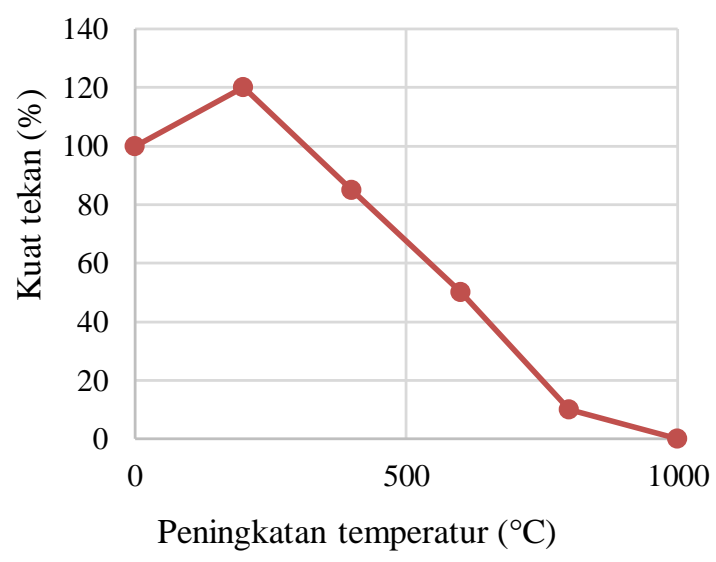

\section{Gambar 1. Grafik peningkatan temperatur dengan persentase penurunan nilai kuat tekan beton (Faizin et al., 2017)}

Degradasi tersebut terjadi karena proses dekomposisi C-S-H yang terurai menjadi Calcium Oxide $(\mathrm{CaO})$ dan Silicon Dioksida $(\mathrm{SiO} 2)$ atau yang dikenal dengan Silika. Hal ini juga dapat terjadi karena perbedaan nilai kembang susut antara agregat dan pasta semen (Faizin et al., 2017). 
Beton termasuk material struktur bangunan yang relatif tahan terhadap api dibandingkan dengan material konstruksi lain seperti kayu ataupun baja. Akibat panas yang berlebih, beton dapat mengalami retak, terkelupas (spalling), dan kehilangan kekuatan. Secara visual pengaruh dari kebakaran terhadap beton dapat dilihat berubahnya warna pada beton (Anggraini \& Wahjuni, 2011).

Secara fisik dapat dilihat langsung (secara visual) pengaruh dari kebakaran terhadap beton yaitu berubahnya warna pada beton. Apabila temperatur pada beton melebihi $300^{\circ} \mathrm{C}$ warna pada beton akan berubah menjadi merah muda. Jika temperatur beton melebihi $600^{\circ} \mathrm{C}$ warna pada beton akan berubah menjadi abu-abu agak hijau, jika temperatur beton melebihi $900^{\circ} \mathrm{C}$ berubah warna menjadi abu-abu dan jika temperatur beton diatas $1200^{\circ} \mathrm{C}$ akan berubah warna menjadi kuning.

Salah satu metode pemodelan struktur untuk menganalisis beton yang terpapar suhu adalah dengan metode elemen hingga. Metode elemen hingga merupakan proses perhitungan secara numerik dengan mengkombinasikan beberapa konsep matematika untuk menghasilkan persamaan sistem linier atau nonlinier. Pada metode elemen hingga, suatu konstruksi yang dikenai gaya seperti beban, tekanan dan temperatur dapat menimbulkan dampak perubahan bentuk (deformasi) yang dinyatakan dengan perpindahan (displacement).

Metode elemen hingga ini menggunakan pendekatan diskretisasi elemen untuk menemukan perpindahan titik simpul/join dan gaya-gaya yang terjadi pada struktur. Diskretisasi elemen ini mengacu pada metode matriks untuk menganalisis struktur. Diskretisasi yang dilakukan dapat berupa elemen satu dimensi (elemen garis), dua dimensi (elemen bidang) atau tiga dimensi (elemen solid).

Penelitian ini menggunakan metode elemen hingga dalam program analisis struktur LUSAS (London University Stress Analysis Sistem) versi 16. Ada dua komponen utama pada sistem LUSAS yaitu LUSAS Modeller merupakan user interface untuk pembuatan model dan menampilkan hasil dari analisis dan LUSAS Solver merupakan program analisis yang menggunakan metode elemen hingga untuk menganalisis persoalan yang ada pada LUSAS Modeller.

Sistem yang ada pada LUSAS dapat memodelkan struktur elasto-plastik. Dalam sistem tersebut terdapat dua konsep yang digunakan sebagai dasar perhitungan yaitu continuum formulation dan consistent formulation. Dengan menggabungkan dua metode tersebut dapat meningkatkan kestabilan dalam setiap tingkatan pembebanan dan juga regangan plastik terhadap waktu pada model. Sebelum dilakukannya pemodelan pada software LUSAS, perlu dilakukan analisis regresi pada persamaan penelitian terdahulu untuk mengambil nilai input sifat mekanik beton pada LUSAS. Nilai yang menjadi variabel input sifat mekanik beton pada LUSAS adalah nilai modulus elastisitas, kuat tekan, kuat tarik dan regangan puncak. Parameter input di dalam LUSAS juga dapat menggunakan model persamaan yang telah dihasilkan oleh peneliti terdahulu Lie (1992), Terro (1998), Li \& Purkiss (2005), Chang et al (2006). Namun dalam penelitian ini model persamaan menggunakan model persamaan Li \& Purkiss (2005), serta Chang et al (2006).

Li \& Purkiss (2005) membuat sebuah penelitian tentang hubungan tegangan dan regangan pada material beton ketika adanya peningkatan temperatur. Pada penelitiannya Li dan Purkiss membandingkan model dan data pengujian eksperimental yang sudah ada sebelumnya tentang sifat mekanik beton saat terjadinya peningkatan temperatur. Li dan Purkiss juga membentuk model yang dapat dikombinasikan dengan program elemen hingga komersial dengan cara membandingkan beberapa data tersebut. Pada penelitian tersebut $\mathrm{Li}$ dan Purkiss memberikan contoh perhitungan pada elemen dinding yang dipanaskan.

Berdasarkan penelitian Li dan Purkiss didapatkan kesimpulan bahwa kurva yang terbentuk dengan menggunakan persamaan Eurocode 2: EN 1992-1-2 tidak cocok digunakan untuk menganalisis beton dengan regangan puncak yang tinggi sedangkan tegangannya besar. Penelitian ini juga menghasilkan persamaan tentang pengaruh temperatur terhadap sifat beton yaitu modulus elastisitas, kuat tekan, dan regangan puncak.

Chang et al (2006) melakukan penelitian tentang hubungan tegangan dan regangan pada beton setelah terpapar temperatur tinggi. Chang dan yang lainnya melakukan pengujian eksperimental dengan memanaskan beton dari temperatur $100^{\circ} \mathrm{C}$ hingga $800^{\circ} \mathrm{C}$. Benda yang diuji merupakan beton berbentuk silinder dengan diameter $15 \mathrm{~cm}$ dan tinggi $30 \mathrm{~cm}$. Proses pendinginan dilakukan setelah pemanasan beton tersebut pada suhu ruangan selama satu bulan sebelum dilakukan pengujian.

Spesimen yang diuji tersebut berjumlah 108 buah dan dua buah adalah beton kondisi normal tanpa dilakukan pemanasan. Penelitian ini memberikan kesimpulan bahwa semakin tinggi temperatur kurva tegangan regangan yang terbentuk semakin datar. Penelitian ini menghasilkan persamaan pengaruh temperatur terhadap sifat mekanik beton yaitu 
modulus elastisitas, kuat tekan, kuat tarik dan regangan puncak.

Dalam hal memulihkan struktur yang telah terbakar perlu diketahui bagaimana perilaku beton ketika terpapar suhu yang tinggi. Untuk itu penelitian ini bertujuan menganalisis perilaku tegangan dan regangan beton saat terbakar dengan pemodelan numerik sehingga dapat dimanfaatkan dalam mengevaluasi bangunan yang telah terbakar. Untuk mengidentifikasi kekuatan beton selain dengan melakukan pengujian secara eksperimental, dapat juga dilakukan dengan pemodelan. Pemodelan ini dilakukan sebagai alternatif pengujian eksperimental karena dapat mensimulasikan pengujian dalam berbagai kondisi dengan peralatan, waktu dan biaya yang sedikit. Pemodelan ini merupakan proses simulasi secara matematis yang didasari pengujian eksperimental sebelumnya. Untuk itu dalam mencapai tujuan penelitian, pemodelan struktur yang terpapar suhu tinggi dimodelkan dengan Program LUSAS Versi 16.

\section{Metode}

Pada penelitian ini digunakan beberapa model persamaan untuk menghitung pengaruh dari temperatur terhadap parameter kemampuan mekanik dari beton. Model persamaan tersebut diambil dari penelitian yang sudah ada sebelumnya, antara lain model persamaan Li \& Purkiss (2005), serta Chang et al (2006).

Nilai perhitungan pengaruh suhu berdasarkan parameter model. Parameter yang dihitung adalah modulus elastisitas, kuat tekan, kuat tarik dan regangan puncak. Setelah parameter didapatkan dari perhitungan maka dilakukan pemodelan dengan program LUSAS. Pada program LUSAS, model yang digunakan yaitu beton berbentuk silinder dengan ukuran diameter $150 \mathrm{~mm}$ dan tinggi $300 \mathrm{~mm}$. Untuk pembebanan digunakan beban yang terbagi secara merata di permukaan atas beton silinder. Pembebanan dilakukan secara bertahap setiap $1 \mathrm{MPa}$. Kondisi awal beton sebelum disimulasikan pada temperatur tinggi dapat dilihat pada Tabel 1.

Tabel 1. Parameter awal beton kondisi normal

\begin{tabular}{lll}
\hline \multicolumn{1}{c}{ Parameter } & \multicolumn{1}{c}{ Nilai } & Satuan \\
\hline Mutu beton $\left(\mathrm{f}^{\prime} \mathrm{c}\right)$ & 25 & $\mathrm{MPa}$ \\
Modulus Elastisitas $\left(\mathrm{E}_{0}\right)$ & 23500 & $\mathrm{MPa}$ \\
Poisson ratio & 0,2 & \\
Berat volume beton & 2400 & $\mathrm{Kg} / \mathrm{m}^{3}$ \\
Temperatur awal $\left(\mathrm{T}_{0}\right)$ & 20 & ${ }^{\circ} \mathrm{C}$ \\
\hline
\end{tabular}

Sifat elastis dari beton dapat berkurang ketika terjadi peningkatan temperatur. Penurunan modulus elastisitas ini dapat dihitung dengan model numerik yang dirumuskan di dalam British Standard Institution (BSI) : BS 8110, Li \& Purkiss (2005) dan Chang et al (2006) dengan persamaan berikut:

BSI:

$E_{T}=\left(\frac{700-T}{550}\right) E_{0} \quad \leq E_{0}$

Li dan Purkiss :

$E_{T}=\left(\frac{800-T}{740}\right) E_{0} \leq E_{0}$

Chang :

$E_{T}=\left\{\begin{array}{cc}(-0.00165 T+1.033) E_{0} & 20^{\circ} \mathrm{C}<T \leq 125^{\circ} \mathrm{C} \\ \left(1 /\left(1.2+18(0.0015 T)^{4.5}\right)\right. & 125^{\circ} \mathrm{C}<T<800^{\circ} \mathrm{C}\end{array}\right\}$

ET merupakan modulus elastisitas pada kondisi peningkatan temperatur, E0 merupakan modulus elastisitas pada kondisi normal, dan T merupakan temperatur. Persyaratan untuk nilai modulus elastisitas yang diinput di dalam LUSAS yaitu $1,1 \mathrm{f}^{\prime} \mathrm{cT} / \mathrm{ET}$ lebih besar dan sama dengan 0.005 , dengan begitu persamaan hasil regresi adalah sebagai berikut.

$20^{\circ} \mathrm{C}<T \leq 600^{\circ} \mathrm{C}$ :

$E_{T}=E_{0}\left(1.24 \times 10^{-6} T^{2}-2.45 \times 10^{-3} T+1.12\right)$

$600^{\circ} \mathrm{C}<T \leq 700^{\circ} \mathrm{C}$ :

$E_{T}=\frac{f^{\prime}{ }^{\prime} T}{0,005}$

dengan f'cT adalah kuat tekan beton pada temperatur tertentu

Kuat tekan beton dapat berkurang seiring dengan peningkatan temperatur. Reduksi kekuatan yang terjadi akibat dari peningkatan temperatur dapat diperkirakan dengan beberapa persamaan model. Pada penelitian ini reduksi dihitung dengan persamaan model dari Eurocode 2 : 1992-1-2, Li \& Purkiss (2005) dan Chang et al (2004).

EN 1992-1-2 :

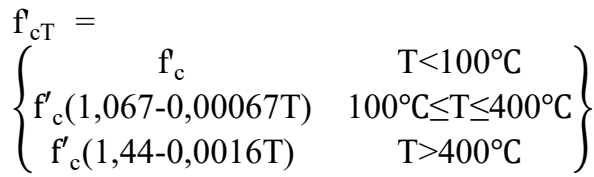

Li dan Purkiss:

$$
\begin{aligned}
\mathrm{f}_{\mathrm{cT}}= & \mathrm{f}_{\mathrm{c}}\left(0,00165\left(\frac{\mathrm{T}}{100}\right)^{3}-0,03\left(\frac{\mathrm{T}}{100}\right)^{2}\right. \\
& \left.+0,025\left(\frac{\mathrm{T}}{100}\right)+1,002\right)
\end{aligned}
$$

Chang:

$\mathrm{f}_{\mathrm{cT}}=\left\{\begin{array}{lc}\mathrm{f}_{\mathrm{c}}(1,01-0,00055 \mathrm{~T}) & 20^{\circ} \mathrm{C}<\mathrm{T} \leq 200^{\circ} \mathrm{C} \\ \mathrm{f}_{\mathrm{c}}(1,15-0,00125 \mathrm{~T}) & 200^{\circ} \mathrm{C}<\mathrm{T} \leq 800^{\circ} \mathrm{C}\end{array}\right\}$ 
dengan f'cT adalah kuat tekan pada kondisi peningkatan temperatur. Sedangkan f'c adalah kuat tekan pada kondisi normal.

Pada perhitungan reduksi kuat tekan, temperatur merupakan nilai variabel. Temperatur yang divariasikan mulai dari temperatur kondisi normal $20^{\circ} \mathrm{C}$ hingga $700^{\circ} \mathrm{C}$. Nilai temperatur dinaikan setiap $100^{\circ} \mathrm{C}$. Pada temperatur $700^{\circ} \mathrm{C}$ kuat tekan beton menjadi $18 \%$, maka persamaan regresi dari penurunan kuat tekan beton adalah sebagai berikut

$20^{\circ} \mathrm{C}<T \leq 100^{\circ} \mathrm{C}$

$\mathrm{f}_{\mathrm{cT}}=\mathrm{f}_{\mathrm{c}}\left(1-0,04 \frac{T}{100}\right)$

$100^{\circ} \mathrm{C}<T \leq 800^{\circ} \mathrm{C}$

$\mathrm{f}_{\mathrm{cT}}=\mathrm{f}_{\mathrm{c}}\left(-9,-x 10^{-7} T^{2}-3,9 \times 10^{-3} T+\right.$ $1,015)$

Persamaan empiris yang dapat menghubungkan kuat tekan dan kuat tarik beton adalah sebagai berikut.

$\mathrm{f}_{\mathrm{cr}}=0,3\left(\mathrm{f}_{\mathrm{c}}\right)^{2 / 3}$

dengan f'cr merupakan kuat tarik beton pada kondisi normal, dan f'crT merupakan kuat tarik beton pada peningkatan temperatur. Reduksi kekuatan yang terjadi akibat dari peningkatan temperatur dapat diperkirakan dengan model numerik. Pada penelitian ini reduksi dihitung dengan persamaan model dari Eurocode 2 (EN 1992-1-2, 2002) , Terro (1998) dan Chang et al (2006).

EN 1992-1-2 :

$\mathrm{f}_{\text {crT }}^{\prime}=\mathrm{k}_{\mathrm{crT}} \mathrm{f}_{\text {cr }}$

$\mathrm{k}_{\mathrm{crT}}=\left\{\begin{array}{cc}1 & 20^{\circ} \mathrm{C} \leq \mathrm{T} \leq 100^{\circ} \mathrm{C} \\ 1-(\mathrm{T}-100 / 500) & 100^{\circ} \mathrm{C}<\mathrm{T} \leq 600^{\circ} \mathrm{C}\end{array}\right\}$

Terro :

$\mathrm{f}^{\prime}{ }_{\mathrm{crT}}=\mathrm{f}^{\prime}{ }_{\mathrm{cr}}\left(\mathrm{f}^{\prime}{ }_{\mathrm{cT}} / \mathrm{f}_{\mathrm{c}}\right)$

Chang :

$\mathrm{f}_{\text {crT }}^{\prime}=\left\{\begin{array}{cc}\mathrm{f}^{\prime}{ }_{\mathrm{cr}}(1,05-0,0025 \mathrm{~T}) & 20^{\circ} \mathrm{C} \leq \mathrm{T} \leq 100^{\circ} \mathrm{C} \\ \mathrm{f}^{\prime}{ }_{\mathrm{cr}}(0,8) & 100^{\circ} \mathrm{C}<\mathrm{T} \leq 200^{\circ} \mathrm{C} \\ \mathrm{f}^{\prime}{ }_{\mathrm{cr}}(1,02-0,0011 \mathrm{~T}) & 200^{\circ} \mathrm{C}<\mathrm{T} \leq 800^{\circ} \mathrm{C}\end{array}\right\}$

dengan $\mathrm{f}_{\text {crT }}$ merupakan kuat tarik pada kondisi peningkatan temperatur dan $\mathrm{f}^{\prime}{ }_{\mathrm{cr}}$ merupakan kuat tarik pada kondisi normal. Pada perhitungan reduksi kuat tarik, temperatur merupakan nilai variabel. Temperatur yang divariasikan mulai dari temperatur kondisi normal $20^{\circ} \mathrm{C}$ hingga $700^{\circ} \mathrm{C}$. Kenaikan temperatur dilakukan setiap $100^{\circ} \mathrm{C}$. Pada temperatur $700^{\circ} \mathrm{C}$ kuat tarik yang tersedia tinggal $16 \%$, dengan begitu persamaan regresi yang terbentuk adalah sebagai berikut: $\mathrm{f}_{\text {crT }}^{\prime}=\mathrm{f}_{\text {cr }}\left(-1,8 \times 10^{-7} T^{2}-1,1 \times 10^{-3} T+1,04\right)$

Peningkatan temperatur yang terjadi pada beton memperbesar nilai regangan pada tegangan maksimum. Persamaan yang digunakan pada penelitian ini berdasarkan persamaan Lie (1992), Li $\&$ Purkiss (2005) dan Chang et al (2006).

Lie :

$\varepsilon_{\mathrm{uT}}=0,0025+\left(6,0 \mathrm{~T}+0,04 \mathrm{~T}^{2}\right) \times 10^{-6}$

Li dan Purkiss :

$\varepsilon_{\mathrm{uT}}=\frac{2 \mathrm{f}_{\mathrm{c}}}{\mathrm{E}_{0}}+0,21 \times 10^{-4}(\mathrm{~T}-20)-0,9 \mathrm{x}$

$10^{-8}(\mathrm{~T}-20)^{2}$

Chang :

$20^{\circ} \mathrm{C}<\mathrm{T} \leq 200^{\circ} \mathrm{C}$

$\varepsilon_{\mathrm{uT}}=\varepsilon_{\mathrm{uT}}$

$200^{\circ} \mathrm{C}<\mathrm{T} \leq 800^{\circ} \mathrm{C}$

$\varepsilon_{\mathrm{uT}}=\varepsilon_{\mathrm{u}}\left(-0,1 \mathrm{f}^{\prime}{ }_{\mathrm{c}}+7,7\right)$

$\left[\frac{\exp (-5,8+0,01 \mathrm{~T})}{1+\exp (-5,8+0,001 \mathrm{~T})}-0,0219\right]+1,0$

dengan euT merupakan regangan puncak pada kondisi peningkatan temperatur dan eu merupakan regangan puncak pada kondisi normal.

Pada perhitungan regangan puncak, temperatur merupakan nilai variabel. Temperatur yang divariasikan mulai dari temperatur kondisi normal $20^{\circ} \mathrm{C}$ hingga $700^{\circ} \mathrm{C}$. Temperatur akan dinaikan setiap $100^{\circ} \mathrm{C}$.

Dengan demikian persamaan regresi yang dapat terbentuk adalah sebagai berikut.

$\varepsilon_{\mathrm{uT}}=\frac{\mathrm{f}_{\mathrm{c}}}{\mathrm{E}_{0}}(0,0084 \mathrm{~T}+1,6)$

Setelah perumusan persamaan tegangan-regangan menggunakan persamaan Lie (1992), (Li \& Purkiss, 2005) dan Chang et al (2006). Langkah pemodelan selanjutnya dilakukan menggunakan software LUSAS dengan membuat geometri dari model benda uji. Spesimen yang dimodelkan adalah beton dengan mutu $25 \mathrm{MPa}$ berbentuk silinder dengan diameter $150 \mathrm{~mm}$ dan tinggi $300 \mathrm{~mm}$. Selanjutnya yaitu memberikan mesh atau jaringan dengan tipe tetrahedral dan ukuran maksimum $100 \mathrm{~mm}$. Pada LUSAS ada dua tipe sifat material yang diinputkan yaitu sifat elastis dan sifat plastis. Parameter sifat material elastis yang menjadi input yaitu modulus elastisitas, poisson rasio dan berat volume beton. Modulus elastisitas yang digunakan adalah hasil perhitungan yang sudah direduksi akibat adanya peningkatan temperatur. Secara umum nilai poisson rasio bervariasi antara 0,15 untuk beton mutu tinggi dan 0,22 untuk beton mutu rendah, sedangkan yang 
digunakan pada penelitian ini yaitu 0,2. Berat volume untuk beton normal berkisar antara $2.200 \mathrm{~kg} / \mathrm{m}^{3}$ hingga $2.600 \mathrm{~kg} / \mathrm{m}^{3}$ dan yang digunakan pada penelitian ini yaitu $2.400 \mathrm{~kg} / \mathrm{m}^{3}$. Selanjutnya yaitu sifat plastis material, yang menjadi input yaitu kuat tekan, kuat tarik dan nilai regangan puncak.

\section{Hasil dan Pembahasan}

Penurunan modulus elastisitas ini telah dihitung menggunakan model numerik yaitu oleh British Standard Institution (BSI) : BS 8110, Li \& Purkiss (2005) dan Chang et al (2006). Pada perhitungan reduksi modulus elastisitas, temperatur merupakan variabel pada perhitungan tersebut. Temperatur yang divariasikan mulai dari temperatur kondisi normal $20^{\circ} \mathrm{C}$ hingga $700^{\circ} \mathrm{C}$ dan mengalami kenaikan setiap $100^{\circ} \mathrm{C}$. Setiap model yang telah dilakukan perhitungan dapat dihubungkan menjadi sebuah grafik. Grafik yang terbentuk dibuat dalam bentuk trendline dengan bantuan software Excel seperti terlihat pada Gambar 2. Nilai modulus elastisitas berdasarkan temperatur yang diinputkan pada LUSAS. Berdasarkan Gambar 2 dapat dilihat bahwa modulus elastisitas terus berkurang seiring dengan peningkatan temperatur. Pada temperatur $100^{\circ} \mathrm{C}$ modulus elastisitas yang tersedia adalah $88 \%$ dari modulus awalnya.

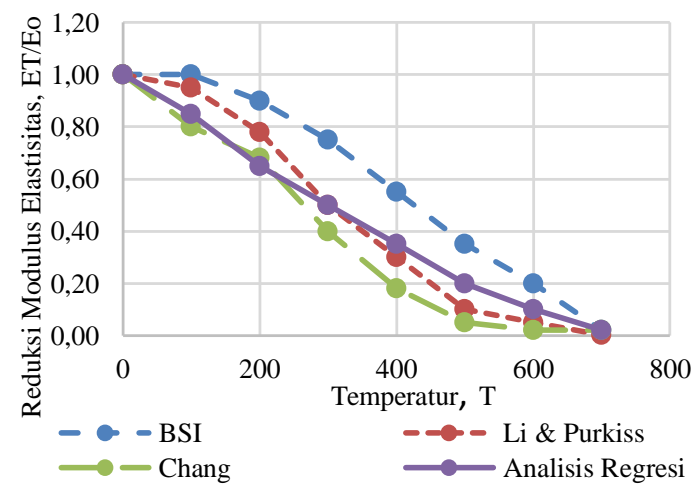

Gambar 2. Grafik modulus elastisitas terhadap peningkatan temperatur

Pada temperatur $600^{\circ} \mathrm{C}$ modulus elastisitas yang tersisa adalah $11 \%$. Kuat tekan beton saat temperatur $300^{\circ} \mathrm{C}$ masih tersedia $81 \%$ dari kekuatan awal. Pada temperatur $700^{\circ} \mathrm{C}$ kuat tekan beton menjadi $18 \%$, maka persamaan regresi dari penurunan kuat tekan beton dapat digambarkan seperti terlihat pada Gambar 3. Kuat tarik pada beton merupakan kemampuan beton untuk menerima beban tarik. Kuat tarik ini juga berfungsi sebagai penahan retak pada beton ketika beton menerima beban. Ketika kuat tekan beton meningkat, maka kuat tarik beton juga akan meningkat. Kuat tarik beton dapat diketahui dari seberapa besar kuat tekan dari beton dengan sebuah angka faktor. Hasil perhitungan persamaan regresi model benda uji ditampilkan dalam grafik dengan trendline. Trendline tersebut dibuat dengan bantuan MS Excel seperti pada Gambar 4. Berdasarkan trendline tersebut, maka nilai kuat tarik ditentukan berdasarkan temperatur yang menjadi input pada program LUSAS. Gambar 4 menggambarkan temperatur $200^{\circ} \mathrm{C}$ beton masih memiliki kuat tarik sebesar $82 \%$ dari kekuatan awalnya.

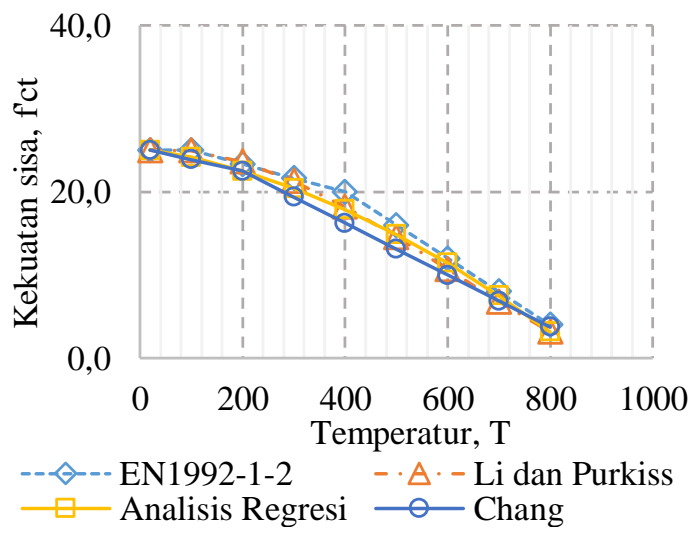

\section{Gambar 3. Grafik kuat tekan terhadap peningkatan temperatur}

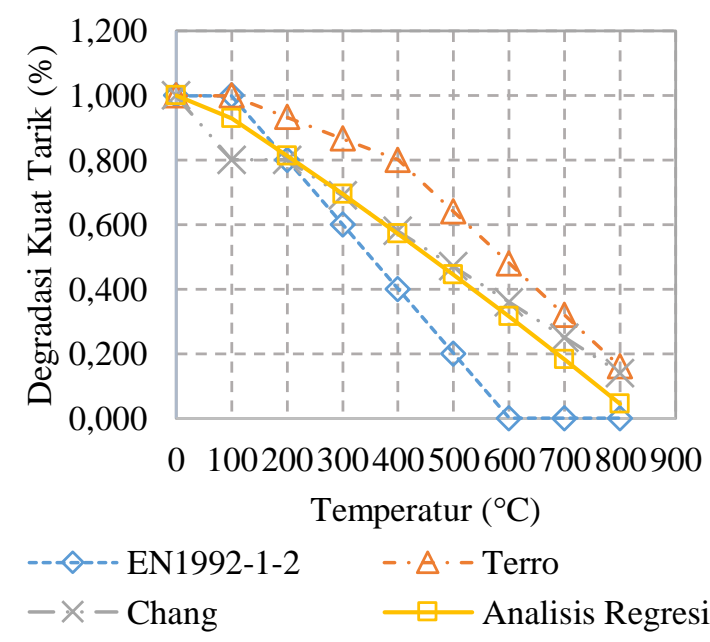

\section{Gambar 4. Grafik kuat tarik terhadap peningkatan temperatur}

Perhitungan regangan puncak beton pada kenaikan temperatur menggunakan model persamaan Li \& Purkiss (2005) telah menghasilkan regangan puncak beton seperti terlihat pada Tabel 2 . Berdasarkan Tabel 2 dapat dilihat bahwa peningkatan temperatur dapat mempengaruhi regangan puncak yang terjadi saat tegangan maksimum diterima beton. Hasil perhitungan berdasarkan model Li \& Purkiss pada temperatur $20^{\circ} \mathrm{C}$ sampai dengan temperatur $700^{\circ} \mathrm{C}$ regangan puncak terus meningkat. Saat temperatur $20^{\circ} \mathrm{C}$ regangan puncak adalah 0,0019 dan ketika temperatur $300^{\circ} \mathrm{C}$ regangan puncak meningkat menjadi $343,3 \%$. Regangan tersebut terus 
meningkat hingga pada temperatur $700^{\circ} \mathrm{C}$ regangan menjadi $612,5 \%$ seperti pada Gambar 5.

\begin{tabular}{ccc}
\multicolumn{3}{c}{$\begin{array}{c}\text { Tabel 2. Perhitungan regangan puncak beton } \\
\text { berdasarkan persamaan Li \& Purkiss (2005) }\end{array}$} \\
\hline $\begin{array}{c}\text { Temperatur } \\
\left({ }^{\circ} \mathbf{C}\right)\end{array}$ & $\begin{array}{c}\text { Regangan } \\
\text { puncak }\end{array}$ & $\begin{array}{c}\text { Peningkatan } \\
(\%)\end{array}$ \\
\hline 20 & 0,0021 & 100,0 \\
100 & 0,0038 & 176,3 \\
200 & 0,0056 & 264,0 \\
300 & 0,0073 & 343,2 \\
400 & 0,0088 & 414,0 \\
500 & 0,0101 & 476,3 \\
600 & 0,0113 & 530,2 \\
700 & 0,0122 & 575,6 \\
800 & 0,0130 & 612,5 \\
\hline
\end{tabular}

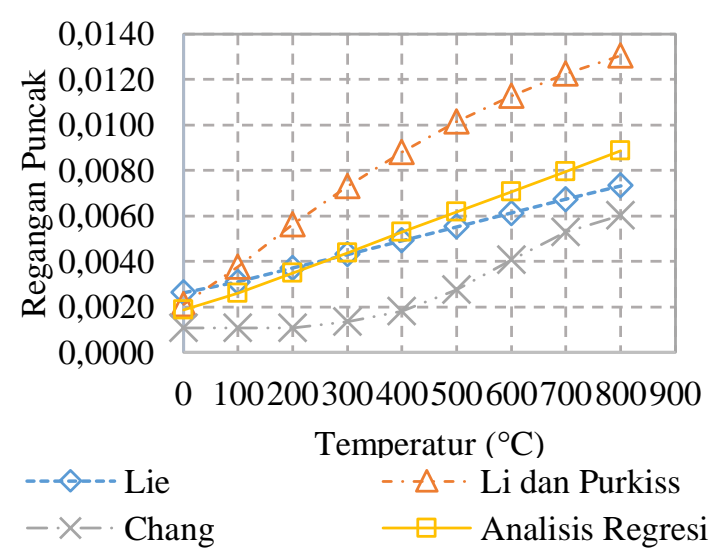

Gambar 5. Grafik regangan puncak beton pada peningkatan temperatur

Tabel 3. Perhitungan regangan puncak beton berdasarkan persamaan Chang et al (2006)

\begin{tabular}{ccc}
\hline $\begin{array}{c}\text { Temperatur } \\
\left({ }^{\circ} \mathbf{C}\right)\end{array}$ & $\begin{array}{c}\text { Regangan } \\
\text { puncak }\end{array}$ & $\begin{array}{c}\text { Peningkatan } \\
(\boldsymbol{\%})\end{array}$ \\
\hline 20 & 0,0011 & 100,0 \\
100 & 0,0011 & 100,0 \\
200 & 0,0011 & 100,0 \\
300 & 0,0014 & 127,6 \\
400 & 0,0018 & 171,6 \\
500 & 0,0028 & 259,0 \\
600 & 0,0041 & 383,7 \\
700 & 0,0053 & 497,4 \\
800 & 0,0060 & 565,9 \\
\hline
\end{tabular}

Perhitungan regangan puncak beton pada kenaikan temperatur menggunakan model persamaan Chang menghasilkan regangan puncak beton seperti terlihat pada Tabel 3. Tabel 3 menampilkan peningkatan temperatur mempengaruhi regangan puncak yang terjadi saat tegangan maksimum diterima beton. Berdasarkan model Chang pada temperatur $20^{\circ} \mathrm{C}$ sampai dengan temperatur $200^{\circ} \mathrm{C}$ regangan puncak sama dengan regangan pada kondisi normal. Selanjutnya saat temperatur $500^{\circ} \mathrm{C}$ regangan puncak meningkat menjadi $259 \%$ hingga pada temperatur $700^{\circ} \mathrm{C}$ regangan puncak menjadi $565,9 \%$ dari ragangan awal.

Simulasi hasil kedua model persamaan di atas divalidasi menggunakan program LUSAS. Setelah menginputkan nilai propertis material, tahap selanjutnya yaitu memberikan perletakan dan pola pembebanan. Perletakan yang digunakan pada model adalah perletakan tipe jepit. Perletakan ini diletakkan pada alas model yang dimaksudkan untuk mencegah deformasi pada daerah tersebut. Pola pembebanan untuk pemodelan ini yaitu pembebanan terdistribusi merata yang diletakkan di atas model. Selanjutnya yaitu menjalankan perhitungan pada program LUSAS dan hasil dari perhitungan LUSAS dapat dilihat pada Gambar 6.

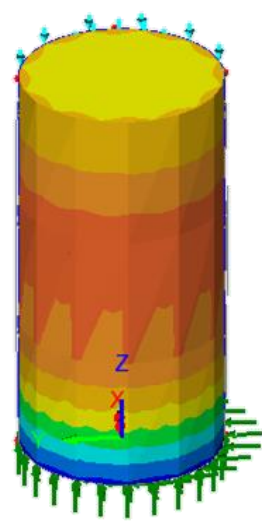

\section{Gambar 6. Tampilan hasil perhitungan LUSAS untuk parameter regangan}

Gambar 6 merupakan tampilan hasil perhitungan dari program LUSAS untuk parameter regangan. Pada gambar dapat terlihat bahwa regangan terbesar terjadi pada tengah model yang ditandai dengan warna merah. Pada alas model terdapat warna biru yang berarti tidak terjadi regangan, hal ini dikarenakan perletakan yang digunakan mencegah regangan yang terjadi. Grafik tegangan regangan beton yang terjadi pada setiap peningkatan temperatur dapat dilihat pada Gambar 7.

Berdasarkan Gambar 7 dapat dilihat bahwa setiap adanya peningkatan temperatur beton akan menjadi lemah. Hal tersebut dapat dilihat pada tegangan maksimum yang turun terjadi di setiap adanya peningkatan temperatur. Pada temperatur $300^{\circ} \mathrm{C}$ tegangan maksimum yang dapat diterima model adalah 20,2 $\mathrm{MPa}$. Pada temperatur $700^{\circ} \mathrm{C}$ tegangan maksimum turun sebesar $80 \%$ dari kekuatan awal menjadi 4,4 $\mathrm{MPa}$. Selain dari kekuatan yang menurun, beton juga mudah terdeformasi. Hal tersebut dapat dilihat pada respon regangan model yang terus meningkat seiring peningkatan temperatur. Pada kondisi normal yaitu temperatur $20^{\circ} \mathrm{C}$ regangan puncak beton adalah Temperatur 
dan Proses Pendinginan 0,0019. Regangan puncak terus meningkat hingga pada temperatur $700^{\circ} \mathrm{C}$ menjadi sebesar 0,0080 .

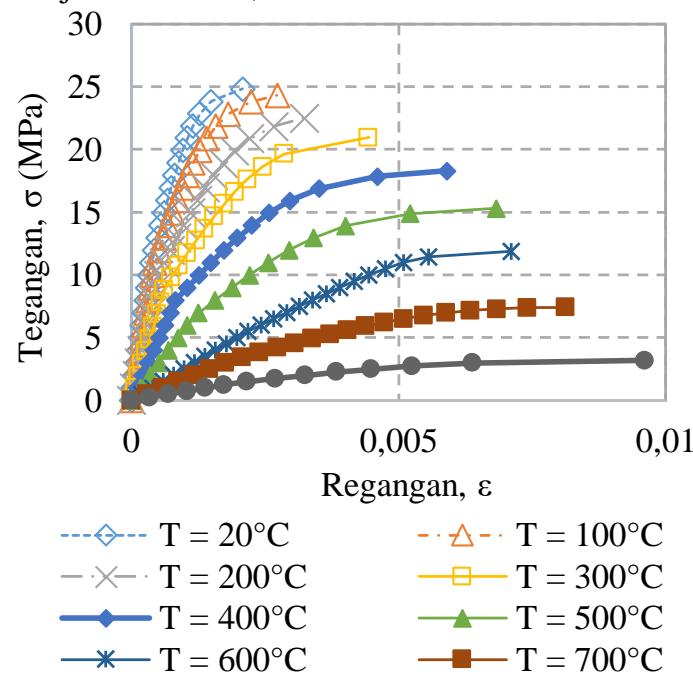

Gambar 7. Grafik tegangan regangan beton pada setiap peningkatan temperatur

\section{Kesimpulan}

Berdasarkan hasil dan pembahasan pada simulasi pengaruh peningkatan temperatur terhadap perilaku tegangan regangan beton, secara umum dapat disimpulkan beberapa hal diantaranya (1) modulus elastisitas beton menurun dari kondisi awal pada temperatur $20^{\circ} \mathrm{C}$ hingga temperatur $700^{\circ} \mathrm{C}$ sebesar 97\%. (2) Kuat tekan beton juga menurun dari kondisi normal hingga temperatur $700^{\circ} \mathrm{C}$ sebesar $80 \%$. (3) Kuat tarik beton menurun sebesar $84 \%$ dari kondisi normal hingga temperatur $700^{\circ} \mathrm{C}$. (4) Regangan puncak beton meningkat seiring peningkatan temperatur, dari kondisi awal hingga temperatur $700^{\circ} \mathrm{C}$ regangan meningkat sebesar $423 \%$. (5) berdasarkan beberapa parameter yang sudah dibahas dapat disimpulkan bahwa beton akan menjadi lemah dan mudah terdeformasi ketika terjadinya peningkatan temperatur.

\section{Ucapan Terima Kasih}

Penulis mengucapkan terima kasih kepada Kementerian Riset, Teknologi dan Pendidikan Tinggi Republik Indonesia atas pendanaan penelitian ini melalui skema Penelitian Dasar 2018 dengan Nomor Kontrak Penelitian Universitas Riau: 289/UN.19.5.1.3/PP/2018. Semoga hasil penelitian ini dapat memberikan kontribusi bagi riset dan teknologi di Indonesia.

\section{Daftar Pustaka}

Anggraini, R., \& Wahjuni, D. E. (2011). Kuat Lentur Balok yang Mengalami Perbedaan. Di presentasikan pada Seminar Nasional BMPTTSSI KoNTekS 5, 69-76.

BS8110. (1997). Structural use of concrete. Code of practice for design and construction. British Standards Institution.

Chang, Y.-F., Chen, Y.-H., Sheu, M.-S., \& Yao, G. C. (2006). Residual Stress-Strain Relationship for Concrete after Exposure to High Temperatures. Cement and Concrete Research, 36(10), 19992005.

Cornelis, R., Hunggurami, E., \& Tokang, N. Y. (2014). Kajian Kuat Tekan Beton Pasca Bakar dengan dan tanpa Perendaman berdasarkan Variasi Mutu Beton. Jurnal Teknik Sipil, III(2), 161-172.

EN 1992-1-2. (2002). EN 1992-1-2: Eurocode 2: Design of Concrete Structures. Part 1.2: General Rules-Structural Fire Design, Brussels.

Faizin, Setyowati, E. W., \& Wisnumurti. (2017). Pengaruh Suhu Tinggi terhadap Lendutan dan Kekakuan Balok Beton Bertulang. Rekayasa Sipil, 11(1), 24-30.

Herlambang, F. S., \& Sudiarta, I. K. (2015). Kuat Tekan Beton Pasca Kebakaran pada Struktur Beton Bertulang di Pasar Seririt, Buleleng, Bali. Logic: Jurnal Rancang Bangun dan Teknologi, 15(1), 23.

Li, L., \& Purkiss, J. (2005). Stress-Strain Constitutive Equations of Concrete Material at Elevated Temperatures. Fire Safety Journal, 40(7), 669-686.

Lie, T. T. (1992). Structural fire protection. American Society of Civil Engineers.

LUSAS. (2017). LUSAS Ver.16. Surrey: United Kingdom.

Nyoman, K. N. (2015). Deteksi Penurunan Kadar Kebasaan Beton Pasca Bakar sebagai Estimasi Awal Terjadinya Korosi pada Baja Tulangan. Spektrum Sipil, 2(1), 22-27.

Rizal, F. (2017). Evaluasi Kekuatan dan Metode Perbaikan Struktur Beton pada Gedung Pasca Kebakaran. PORTAL: Jurnal Teknik Sipil, 2(1).

Sidik, M. (2010). Kajian kuat tekan dan modulus elastisitas beton ringan pasca bakar. Indonesia: Universitas Sebelas Maret.

Terro, M. J. (1998). Numerical Modeling of The Behavior of Concrete Structures in Fire. ACI Structural Journal, 95, 183-193. 